\title{
EVOLUTION AND ORIGIN OF THE MARONIA PLUTON, THRACE, GREECE
}

\author{
Papadopoulou L. ${ }^{1}$, Christofides G. ${ }^{1}$, Koroneos A. ${ }^{1}$, Bröcker M. ${ }^{2}$, Soldatos T. ${ }^{1}$ and \\ Eleftheriadis G. \\ 1 Department of Mineralogy-Petrology-Economic Geology, School of Geology, Aristotle \\ University of Thessaloniki, 541 24, Thessaloniki, lambrini@geo.auth.gr \\ ${ }^{2}$ Institüt für Mineralogie, Correns Str. 24, 48149 Münster, Germany, brocker@nwz.uni- \\ muenster.de
}

\begin{abstract}
The Maronia pluton is the youngest of the Tertiary plutons that occurred in Thrace. Three rock groups have been distinguished: a basic, an intermediate and an acid one. Based on geochemical and isotopic characteristics, the basic group probably represents a magma that isotopically equilibrated with the intermediate group at a certain point of its evolution. The evolution of the intermediate group can be described by an assimilation-fractional crystallization process (AFC). The acid group represents crustal melts that are not genetically related to the basic and intermediate groups. The emplacement of the pluton is related to post-collisional extension resulting from the subduction of the African under the European plate. The magma source of the basic and intermediate group is considered to be a LILE- and LREE-enriched subcontinental lithospheric mantle. The acid group has probably derived by the partial melting of crustal rocks and in particular, gneiss.
\end{abstract}

\section{INTRODUCTION}

During the Tertiary, the Rhodope Massif and the Circum Rhodope Belt in northeastern Greece have been characterized by intense Tertiary magmatism of calc-alkaline to shoshonitic affinity. In this study published and unpublished data are used in order to determine the evolution history of the Maronia pluton, occurring in the Circum Rhodope Belt, and to define the geotectonic environment and the origin of its parental magma.

\section{GEOLOGY}

The Circum Rhodope Belt has been considered a Mesozoic cover of the Rhodope Massif. Recent studies (Ricou et al. 1998) reject this concept and accept the existence of two distinct greenschist belts. In the area of Thrace, the Circum Rhodope Belt is divided into two units: the Makri unit (also known as the phyllite series) and the overlying Drimos-Melia unit (Kouris 1980, Papadopoulos 1982, loannidis 1998).

The age of the Maronia pluton, based on $\mathrm{Rb}-\mathrm{Sr}$ whole rock-biotite isochrones, has been determined as Oligocene (29 Ma) and is considered to be the youngest of the Tertiary plutons that intrude Thrace (Del Moro et al. 1988).

\section{DESCRIPTION OF THE PLUTON}

\subsection{Petrography}

Northwards and westwards the Maronia pluton intrudes marbles of the metasedimentary series of the Makri unit causing a rather wide zone of contact metamorphism (skarn) (Doryphoros 1990). Eastwards it intrudes a metamorphic sequence of phyllites, greenschists and gneisses of the overlying metavolcanosedimentary series of the same unit (Fig. 1) causing intense thermal metamor- 
phism to the surrounding rocks (hornfelses), while southwards the pluton itself is intruded by a small body of porphyritic micro-granite.

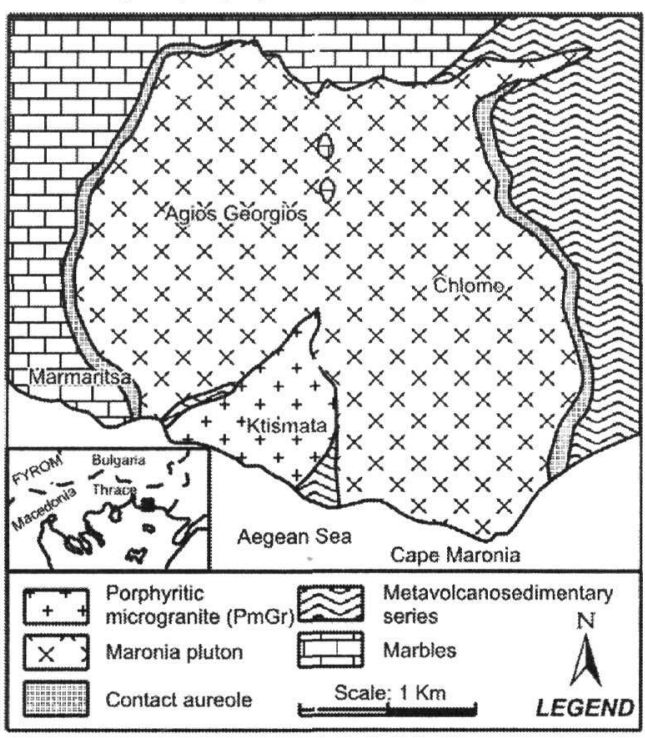

Figure 1. Petrological map of the Maronia pluton.
The petrology and mineralogy of the Maronia pluton have been discussed by Papadopoulou et al. (2001). Here the main rock types and their minerals are described briefly.

Based on the Q'IANOR classification diagram of Streckeisen \& Le Maitre (1979) (Fig. 2), three main rock groups have been distinguished:

a) The basic group that consists of gabbro (Gb), b) the intermediate group that consists of monzogabbro (Mzg), quartz monzogabbro (QMzg), monzonite (Mz), quartz monzonite $(\mathrm{QMz})$ and mafic microgranular enclaves (MME) of Mzg composition, and c) the acid group that consists of granite $(\mathrm{Gr})$ and porphyritic micro-granite (PmGr).

The relationships among the different rock types are not always clear. A few exposures of gabbro are found in the central part of the pluton with no clear relations to the rocks of the intermediate group. The porphyritic micro-granite intrudes both the pluton and the rocks of the metamorphic basement. Granite intrudes and encloses rocks of the intermediate group. In the same group MME are found.

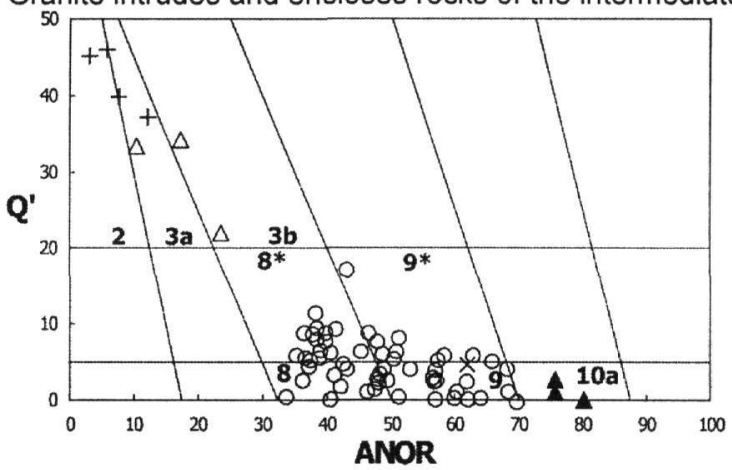

Figure 2. Q'IANOR classification diagram. $\boldsymbol{\Delta}$ = basic group, $O=$ intermediate group, $\Delta=$ acid group (granite), $+=$ acid group (porphyritic micro-granite), $\mathrm{X}=$ enclave.

a) The basic group. $\mathrm{Gb}$ consists mainly of pyroxenes, biotite, plagioclase and $\mathrm{Fe}-\mathrm{Ti}$ oxides and apatite as accessory minerals. K-feldspar is also present in small amounts while olivine is rare.

b) The intermediate group. Mzg shifts to QMzg with an increase of interstitial quartz. Both rock types consist of the same minerals at different proportions, i.e plagioclase, K-feldspar, small amounts of quartz, pyroxenes, biotite, amphibole, FeTi oxides and apatite. The same stands for $\mathrm{Mz}$ which grades to $\mathrm{QMz}$ with a small increase of interstitial quartz. These rock types consist of plagioclase, K-feldspar, small amounts of quartz, pyroxenes, biotite, amphibole, Fe-Ti oxides, apatite and in some cases titanite, chlorite and sericite. The MME are classified as monzogabbro and consist of plagioclase, K-feldspar, small amounts of quartz, amphibole, biotite and clinopyroxene. Titanite, epidote, apatite and Fe-Ti oxides are found as accessory minerals while actinolite and chlorite appear as alteration produsts.

c) The acid group. $\mathrm{Gr}$ appears in the form of dykes containing quartz, K-feldspar, plagioclase, biotite and zircon, rutile, titanite and apatite as accessory minerals. Chlorite, epidote and calcite exist as secondary minerals. PmGr contains phenocrysts of quartz, K-feldspar and a few phenocrysts of plagioclase in a fine-grained groundmass that constitutes of the same minerals. Biotite, epidote, apatite, titanite, zircon and Fe-Ti oxides are also present as accessory minerals. 


\subsection{Geochemistry}

\subsubsection{Major, trace elements and REE}

Representative samples from the plutonic and basement rocks were selected on the basis of their mineralogy, texture, freshness and areal distribution and were analyzed for major, trace elements and REE (Papadopoulou 2003). Average values of each rock type are given in table 1.The REE patterns are shown in figure 3.

Table 1. Average analyses (aver) and standard deviation (std) of each rock type of the Maronia pluton.

\begin{tabular}{|c|c|c|c|c|c|c|c|c|c|c|c|c|c|c|}
\hline & \multirow{2}{*}{\multicolumn{2}{|c|}{$\begin{array}{c}\text { Basic group } \\
\text { Gb (3)* }\end{array}$}} & \multicolumn{8}{|c|}{ Intermediate group } & \multicolumn{4}{|c|}{ Acid group } \\
\hline & & & \multicolumn{2}{|c|}{ Mzg (20) } & \multicolumn{2}{|c|}{$M z(12)$} & \multicolumn{2}{|c|}{ QMzg (10) } & \multicolumn{2}{|c|}{ QMz (14) } & \multicolumn{2}{|c|}{$\operatorname{Gr}(3)$} & \multicolumn{2}{|c|}{ PmGr (4) } \\
\hline & aver & std & aver & std & aver & std & aver & std & aver & std & aver & std & aver & std \\
\hline $\mathrm{SiO}_{2}$ & 48.29 & 1.57 & 52.02 & 1.70 & 54.94 & 0.81 & 55.57 & 2.75 & 56.98 & 0.91 & 70.91 & 4.48 & 76.24 & 2.07 \\
\hline $\mathrm{TiO}_{2}$ & 0.99 & 0.06 & 0.96 & 0.09 & 0.94 & 0.06 & 0.88 & 0.12 & 0.83 & 0.07 & 0.31 & 0.15 & 0.23 & 0.07 \\
\hline $\mathrm{Al}_{2} \mathrm{O}_{3}$ & 15.30 & 1.51 & 16.20 & 1.35 & 15.69 & 0.69 & 16.41 & 0.28 & 16.14 & 0.53 & 14.25 & 0.34 & 13.06 & 1.13 \\
\hline $\mathrm{Fe}_{2} \mathrm{O}_{3}$ & 3.82 & 0.56 & 3.94 & 0.86 & 3.09 & 0.43 & 3.29 & 0.69 & 3.21 & 0.43 & 1.14 & 0.56 & 0.56 & 0.13 \\
\hline $\mathrm{FeO}$ & 6.08 & 0.75 & 4.98 & 0.89 & 4.46 & 0.41 & 4.48 & 0.88 & 3.89 & 0.37 & 1.34 & 0.66 & 0.65 & 0.15 \\
\hline Mno & 0.17 & 0.01 & 0.16 & 0.02 & 0.14 & 0.01 & 0.15 & 0.01 & 0.12 & 0.01 & 0.03 & 0.02 & 0.11 & 0.07 \\
\hline Mgo & 7.69 & 1.81 & 5.60 & 1.05 & 4.73 & 0.62 & 4.21 & 0.57 & 3.73 & 0.57 & 1.06 & 0.72 & 0.25 & 0.18 \\
\hline $\mathrm{CaO}$ & 12.28 & 1.88 & 9.34 & 1.28 & 7.77 & 1.03 & 7.29 & 1.18 & 6.31 & 0.72 & 1.98 & 1.32 & 0.53 & 0.27 \\
\hline $\mathrm{Na}_{2} \mathrm{O}$ & 1.91 & 0.53 & 2.55 & 0.41 & 2.74 & 0.29 & 2.80 & 0.20 & 2.80 & 0.17 & 2.60 & 0.30 & 2.44 & 0.40 \\
\hline $\mathrm{K}_{2} \mathrm{O}$ & 1.61 & 0.44 & 2.90 & 0.53 & 4.28 & 0.42 & 3.46 & 0.46 & 4.68 & 0.31 & 5.87 & 0.22 & 5.36 & 0.28 \\
\hline $\mathrm{P}_{2} \mathrm{O}_{5}$ & 0.74 & 0.10 & 0.55 & 0.12 & 0.49 & 0.05 & 0.43 & 0.05 & 0.50 & 0.11 & 0.16 & 0.06 & 0.05 & 0.02 \\
\hline LOI & 1.14 & 0.45 & 0.72 & 0.39 & 0.50 & 0.47 & 0.70 & 0.30 & 0.46 & 0.27 & 1.46 & 0.60 & 1.52 & 0.21 \\
\hline
\end{tabular}

$(3)^{\star}$ : average of 3 analyses

A genetic relationship between the basic and intermediate group is supported by their geological relationships, mineralogy and their continuous evolutionary trends on Harker diagrams (not shown). On the other hand, although the rocks of the acid group seem to relate genetically to the previous rock groups, the compositional gaps and the subparallel trends observed in certain diagrams as well as the geological relationships do not support any evolutionary relation between this and the other groups (Papadopoulou 2003).

Furthermore, the difference in REE content between $\mathrm{Gr}$ and $\mathrm{PmGr}$ may indicate a possible nongenetic relationship between these two rock types.

On the AFM diagraın (Fig. 4) the Maronia pluton exhibits typical calc-alkaline character. The analyzed samples of the Maronia pluton show high $\mathrm{K}_{2} \mathrm{O}$ contents. The rocks of the basic group are classified as high $\mathrm{K}$ calc-alkaline and those of the intermediate group as shoshonitic on the diagram of Peccerillo \& Taylor (1976) while the rocks of the acid group are classified as ultrapotassic on the diagram of Rickwood (1989) (Fig. 5).

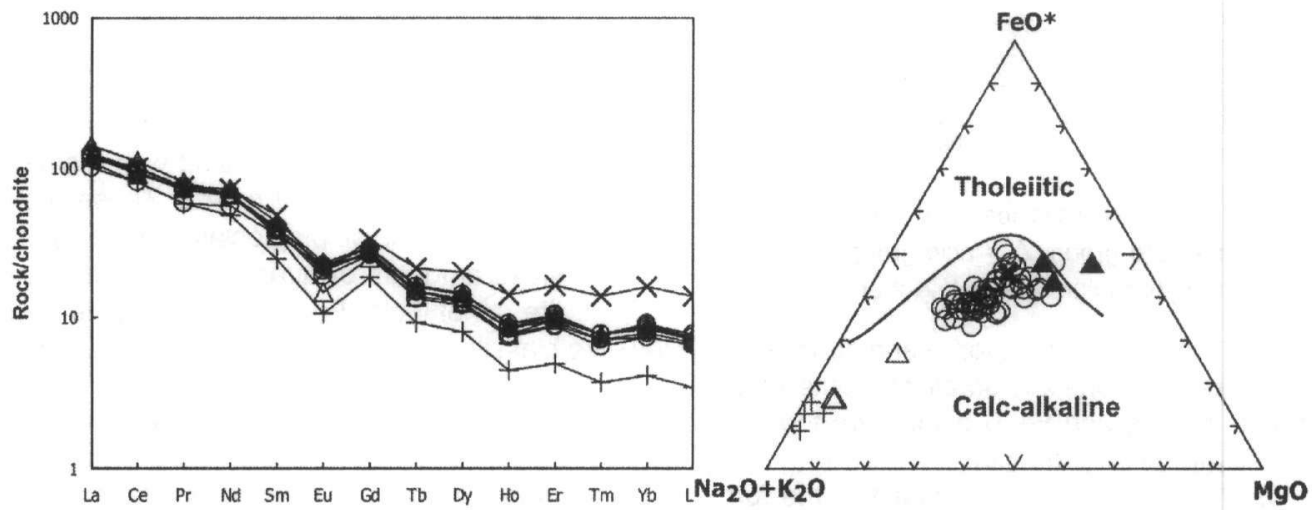

Figure 3. Chondrite-normalised REE patterns of Figure 4. AFM diagram of the Maronia pluton. Symbols selected samples of the Maronia pluton. Normalisation as in figure 2.

factors after Boynton (1984). Symbols as in figure 2. 

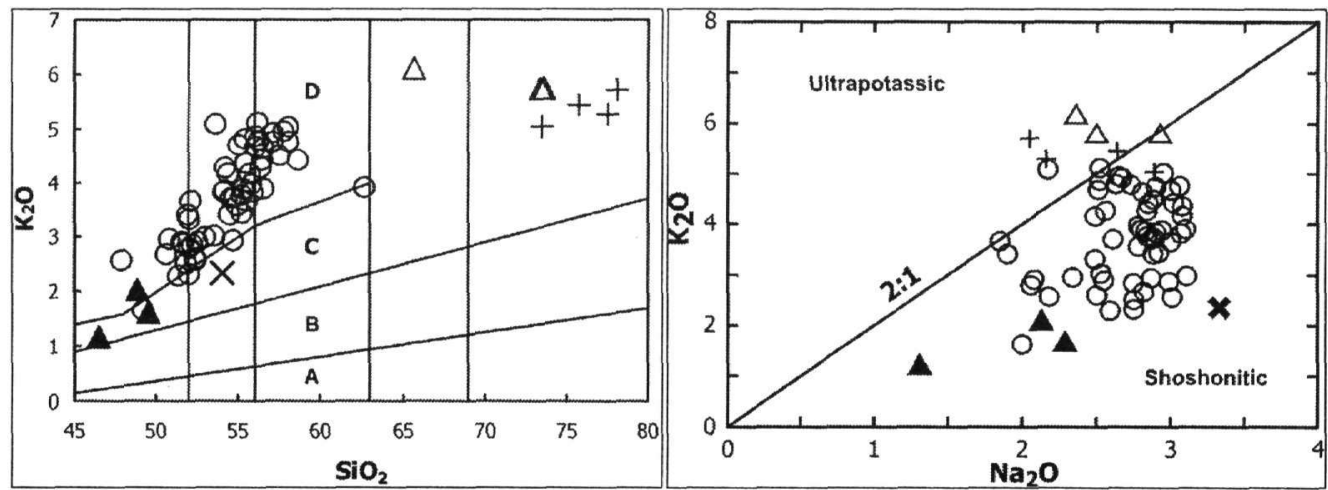

Figure 5. (a) $\mathrm{K}_{2} \mathrm{O}$ vs silica diagram (Peccerillo \& Taylor 1976). $A=$ Low-K series, $B=$ Calc-alkaline series, $C=$ High- $K$ calc-alkaline series, $D=$ Shoshonite series. (b) $\mathrm{K}_{2} \mathrm{O}$ vs $\mathrm{Na}_{2} \mathrm{O}$ diagram (Rickwood 1989). Symbols as in figure 2.

\subsubsection{Isotopic data}

Representative whol z rock samples were analyzed for Sr, O (cf. Papadopoulou et al. 2001) and $\mathrm{Nd}$ isotopes (Tab. 2).

Table 2. Isotopic analyses Sm-Nd of representative rock samples of the Maronia pluton.

\begin{tabular}{|c|c|c|c|c|c|c|c|c|}
\hline Sample & Group & $\begin{array}{c}\text { Sm } \\
(p p m)\end{array}$ & $\begin{array}{c}\text { Nd } \\
\text { (ppm) }\end{array}$ & ${ }^{147} \mathrm{Sm} /{ }^{144} \mathrm{Nd}$ & ${ }^{143} \mathrm{Nd} /{ }^{144} \mathrm{Nd}$ & $2 \sigma$ & $\begin{array}{c}\left({ }^{143} \mathrm{Nd} /{ }^{144} \mathrm{Nd}\right)_{\circ} \\
T=29 \mathrm{Ma}\end{array}$ & $\overline{\varepsilon_{N d}^{t}}$ \\
\hline MP-9A & Intermediate & 9.52 & 44.43 & 0.129551 & 0.512611 & 0.000032 & 0.512586 & -3.27 \\
\hline MP-81 & Intermediate & 7.98 & 40.07 & 0.120391 & 0.512459 & 0.000027 & 0.512436 & 0.29 \\
\hline MP-14 & Intermediate & 8.62 & 48.96 & 0.106475 & 0.512424 & 0.000043 & 0.512404 & -2.64 \\
\hline MP-62 & Intermediate & 7.06 & 36.41 & 0.117246 & 0.512514 & 0.000023 & 0.512492 & -3.44 \\
\hline MP-74 & Intermediate & 7.09 & 36.85 & 0.116252 & 0.512501 & 0.000051 & 0.512479 & -1.56 \\
\hline MP-98 & Intermediate & 6.79 & & 0.119796 & 0.512418 & 0.000054 & 0.512395 & -1.81 \\
\hline MP-90 & Acid & 6.6 & 38.16 & 0.104552 & 0.512442 & 0.000042 & 0.512422 & -2.92 \\
\hline MR-6 & Acid & 4.35 & 24.54 & 0.107227 & 0.512477 & 0.000050 & 0.512457 & -2.24 \\
\hline MT-7 & Basement & 7.54 & 52.69 & 0.086512 & 0.512289 & 0.000044 & 0.512273 & -5.83 \\
\hline
\end{tabular}

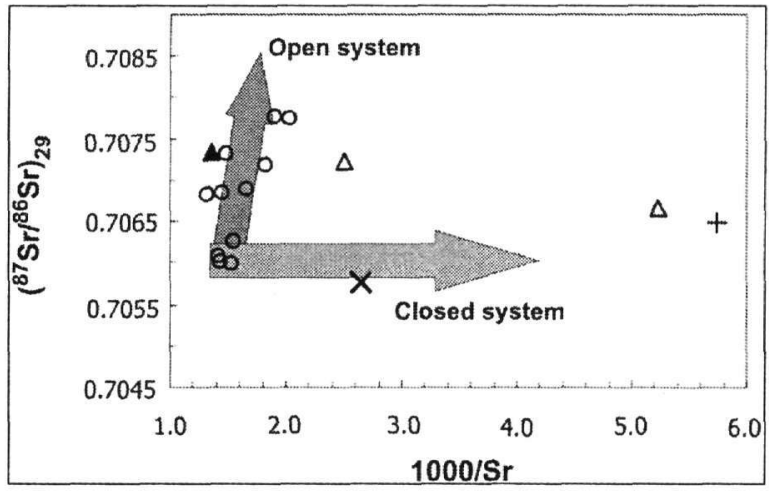

Figure 6. $\left({ }^{87} \mathrm{Sr}{ }^{86} \mathrm{Sr}\right)_{0}$ vs $\mathrm{SiO}_{2}$ variation diagram. Symbols as in figure 2.
Accepting an emplacement age of $29 \mathrm{Ma}$ for the plutonite (Del Moro et al. 1988, Papadopoulou et al. 2001) the $29 \mathrm{Ma}$-based $\mathrm{Sr}$ initial isotopic ratios of the analyzed samples increase with 1000/Sr (Fig. 6). The Nd initial isotopic ratios, based on the $29 \mathrm{Ma}$ emplacement age of the pluton, are plotted against $\mathrm{SiO}_{2}$ (Fig 7). As shown, the enclave has the highest $\mathrm{Nd}$ initial isotopic ratio while the rocks of the intermediate and acid group have lower values ranging from 0.51239 to 0.51249 . The $\delta^{18} \mathrm{O}$ value increases with $\mathrm{SiO}_{2}$ from 7.06 to 8.29 in the intermediate group and from 9.13 to 11.33 in the acid group (Fig 8). 


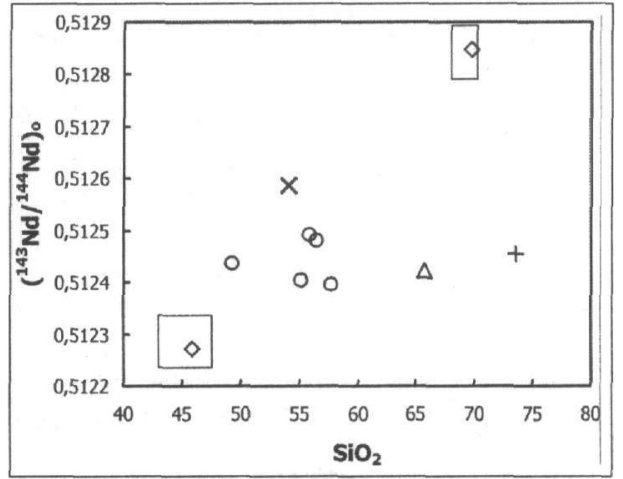

Figure 7. $\left({ }^{143} \mathrm{Nd} /{ }^{144} \mathrm{Nd}\right)$ 。 vs $\mathrm{SiO}_{2}$ variation diagram. Symbols as in figure 2 .

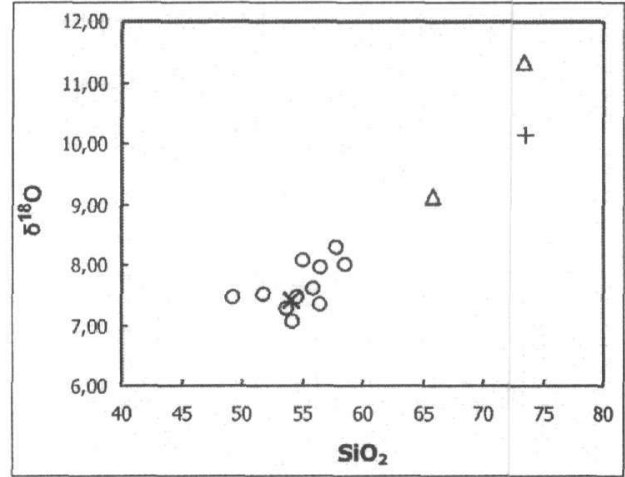

Figure $8 . \delta^{18} \mathrm{O}$ vs $\mathrm{SiO}_{2}$ variation diagram. Symbols as in figure 2 .

\section{EVOLUTION}

In the diagram $\left({ }^{87} \mathrm{Sr} /{ }^{86} \mathrm{Sr}\right)_{0}$ vs $1000 / \mathrm{Sr}$ (Fig. 6), the members of the acid group have lower $\mathrm{Sr}$ initial isotopic values than the more evolved members of the intermediate group. This supports the suggestion that the rocks of the acid group are not genetically related to the rocks of the basicintermediate group, as observed on certain Harker diagrams.

The monzogabbroic enclave has the lowest $\mathrm{Sr}$ and the highest $\mathrm{Nd}$ isotopic ratio suggesting that it is the less evolved sample of the plutonic suite. It might represent a separate magma that intruded the pluton at some point of its crystallization history.

The steep trend shown by the basic-intermediate group (Fig. 6) indicates an open-system evolution. Three are the possible evolution processes that account for the $\mathrm{Sr}$ initial isotopic variability: a) mixing of magmas (MM), b) assimilation and fractionational crystallization (AFC) and c) mixing and fractionational crystallization (MFC). In the two latter cases, one end member should be a mafic magma with a low initial isotopic ratio. If MFC is the evolution process, then the other end member should be an acid magma with a high isotopic ratio while in the case of AFC, the other end member should be a rock that represents the crust.

What can be seen in figure 6 is that the $\mathrm{Gb}$ sample has higher $\mathrm{Sr}$ initial isotopic value than the more mafic members of the intermediate group. So, although it is more mafic based on major and trace elements, it cannot represent the mafic end member of the evolution process. Therefore, the rocks of the basic group possibly represent a magma that isotopically equilibrated with the members of the intermediate group at a certain point of their evolvement history.

In order to determine the evolution process among the members of the intermediate group logarithmic diagrams of compatible vs incompatible elements were plotted (Fig. 9).
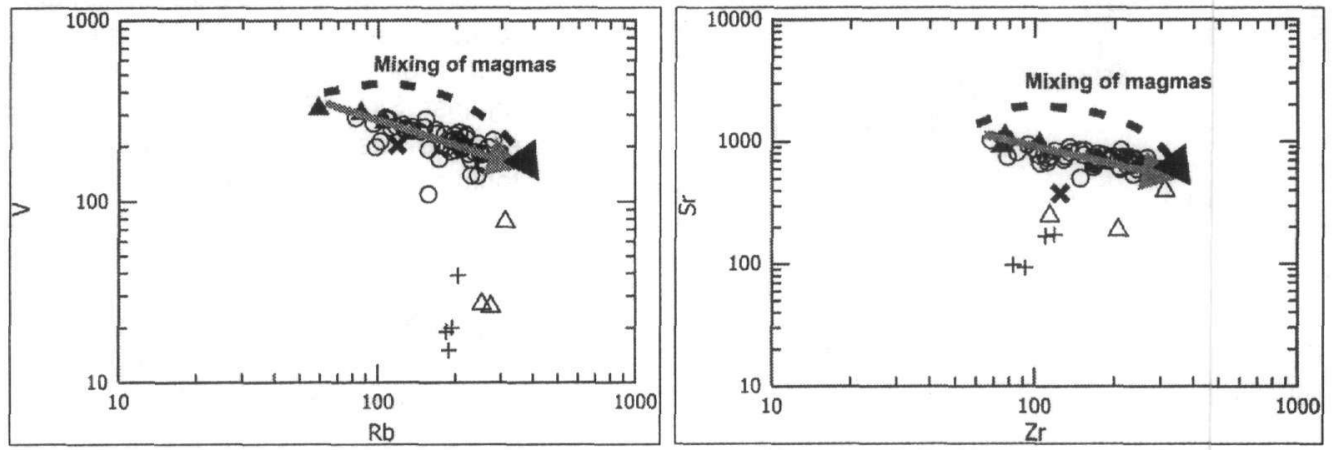

Figure 9. Compatible vs incompatible element ( $\mathrm{ppm})$ variation diagrams of the Maronia pluton. Symbols as in figure 2. 
According to Visonà \& Zanferrari (2000), constancy of incompatible trace element ratios exclude crustal contamination of magmas and provide evidence that fractional crystallization is the dominant evolution proc ess. The same stands for the ratio KJRb (Davidson et al. 1988, Mohamed et al. 2000). The linear trends observed on these diagrams rule out a simple mixing process between two magmas. As shown in figure 10, the dispersion of the intermediate group is attributed to crustal contamination through an AFC process. As a result, an AFC process is considered more likely to have accounted for the evolution of the intermediate group of the Maronia pluton.

To test the AFC process the trace element abundances of sample MP-62 were used as the initial composition $\left(\mathrm{C}^{\circ} \mathrm{m}\right)$ along with those of sample MT-7 that was chosen as the assimilant $\left(\mathrm{C}_{a}\right)$ in the De Paolo (1981) equation. The latter is a schist from the metamorphic basement and is considered to represent the crust (cf. Mason et al. 1996). The intense increase of Sr isotopic ratio led to the acceptance of a valt e $r=0.4$ while the values of the distribution coefficient (D) and the residual melt $(F)$ were allowed to vary in order to simulate the AFC process. Parameters are given in table 3. The curve drawn in figure 11 represents the crystallization path of the intermediate group during AFC process.
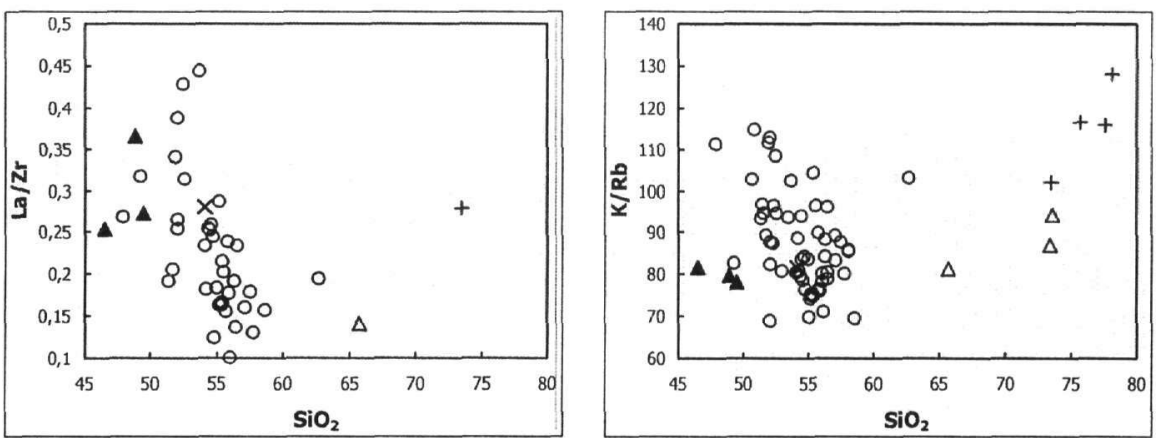

Figure 10. $\mathrm{La} / \mathrm{Zr}$ and $\mathrm{K} / \mathrm{Rb}$ ratios plotted against $\mathrm{SiO}_{2}$. Symbols as in figure 2 .

Table 3. Parameters used in AFC calculations based on trace element concentrations.

\begin{tabular}{lcccc}
\hline & $\mathbf{V}$ & $\mathbf{R b}$ & $\mathbf{S r}$ & $\mathbf{Z r}$ \\
\hline $\mathrm{C}^{\mathrm{o} ; \mathrm{m}}$ & 259 & 117 & 863 & 100 \\
$\mathrm{C}_{\mathrm{a}}$ & 230 & 192 & 787 & 354 \\
$\mathrm{D}$ & 1.3 & 0.61 & 1.3 & 0.82 \\
\hline
\end{tabular}
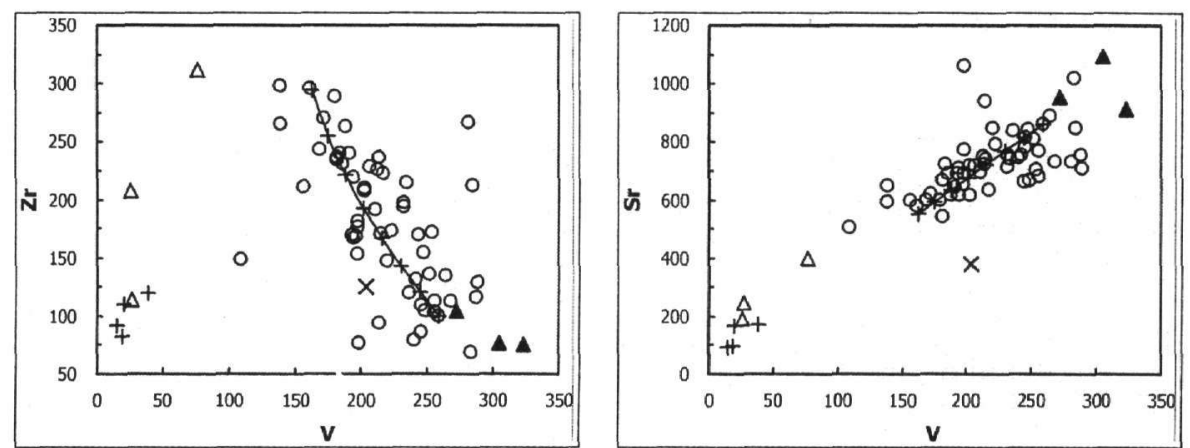

Figure 11. Plots of $\mathrm{Zr}$ and $\mathrm{Sr}$ vs $\mathrm{SiO}_{2}$. Curves show the outcome of $\mathrm{AFC}$ modelling involving the crystallisation of the intermediate group assimilating schist from the metamorphic basement. Symbols as in figure 2 .

Isotopic abundances were also used to simulate the AFC process of the intermediate group. The same samples were chosen as the initial magma and the assimilant (Tab. 4). The theoretical curve in figure 12 represents the AFC process and was drawn for values $r=0.4, D_{S r}=1.3, D_{N d}=$ 
0.1 and $F=1-0.3$. In figure 13 , sample MP-90, which seems to vary from the rest of the acid group, can result from the intermediate group through an AFC process. The AFC curve was constructed for values $r=0.45, D_{S r}=1.85, D_{N d}=0.1$ and $F=1-0.6$. An alternative hypothesis is that this acid member can result through a simple fractional crystallization process from a member of the intermediate group with the same initial $\mathrm{Sr}$ isotopic ratio.

Table 4. Parameters used in AFC modelling based on isotopic concentrations.

\begin{tabular}{lcccc}
\hline & Sr & Nd & $\left({ }^{87} \mathbf{S r} l^{86} \mathrm{Sr}\right)_{0}$ & $\left({ }^{143} \mathrm{Nd} / l^{144} \mathrm{Nd}\right)_{0}$ \\
\hline MP-62 & 699 & 36.41 & 0.705998 & 0.512492 \\
MT-7 & 775.7 & 52.69 & 0.708608 & 0.512273 \\
\hline
\end{tabular}
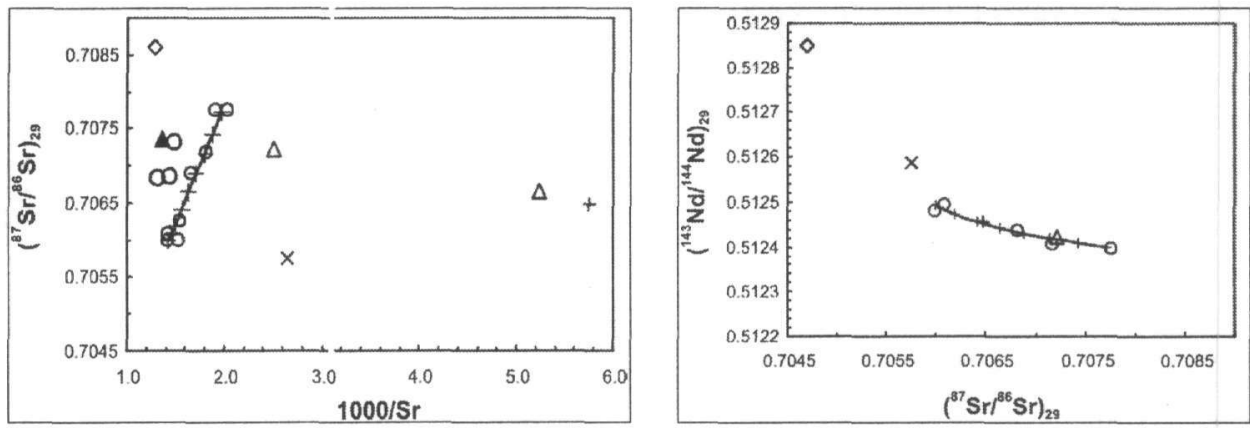

Figure 12. (a) $\left({ }^{87} \mathrm{Sr} /{ }^{86} \mathrm{Sr}\right)_{29}$ vs $1000 / \mathrm{Sr}$ and (b) $\left({ }^{143} \mathrm{Nd} /{ }^{144} \mathrm{Nd}\right)_{29}$ vs $\left({ }^{87} \mathrm{Sr} /{ }^{86} \mathrm{Sr}\right)_{29}$. Curves show the outcome of AFC modelling involving the crystallisation of the intermediate group assimilating schist from the metamorphic basement. Symbols as in figure $2, \diamond=$ metamorphic basement.
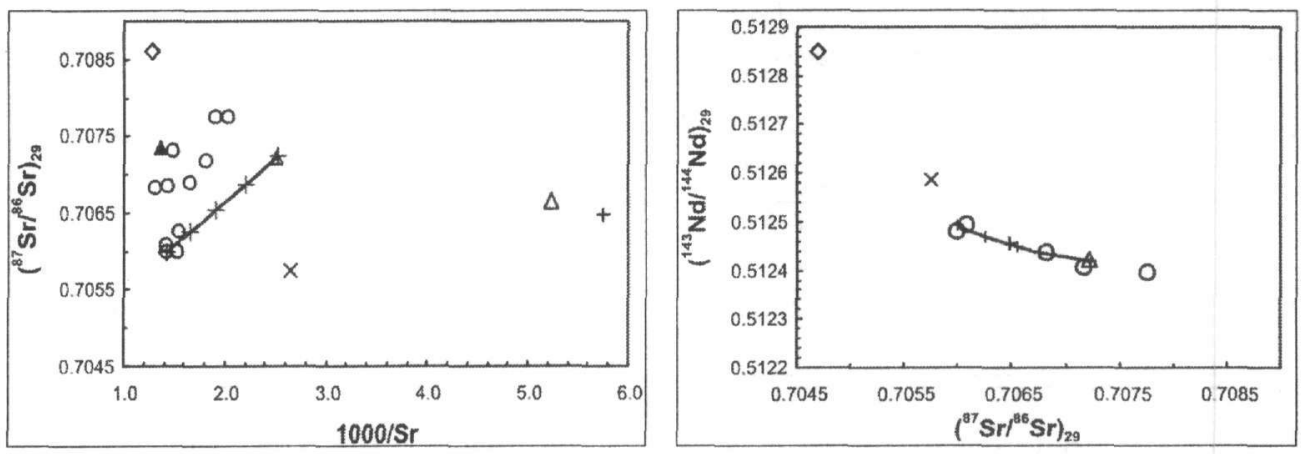

Figure 13. (a) $\left(^{87} \mathrm{Sr} /{ }^{86} \mathrm{Sr}\right)_{29}$ vs $1000 / \mathrm{Sr}$ and (b) $\left({ }^{143} \mathrm{Nd} /{ }^{144} \mathrm{Nd}\right)_{29}$ vs $\left({ }^{87} \mathrm{Sr} /{ }^{86} \mathrm{Sr}\right)_{29}$. Curves show the outcome of AFC modelling involving the crystallisation of $\mathrm{Gr}(\mathrm{MP}-90)$ from the intermediate group assimilating schist from the metamorphic basement. Symbols as in figure $2, \diamond=$ metamorphic basement.

\section{GEOTECTONIC ENVIRONMENT}

Spider patterns normalized to primitive mantle exhibit $\mathrm{Nb}$ and Ti negative anomalies pointing to a subduction related en sironment (Fig. 14). On the R1-R2 diagram of Batchelor \& Bowden (1985) the basic-intermediate groups plot in the fields of pre-plate collision and post-collision uplift while the acid group plots in the syn-collision field (Fig. 15). However, any conclusions regarding the geotectonic setting must be in accordance to the geological history of the broader area (Christofides et al. 1999). In general, potassium-rich igneous activity is a common feature of post-collisional extensional orogens. The magmatic activity that took place in the Rhodope Massif during Lower Oligocene-Upper Miocene is considered to be the result of intensive extension (Pe-Piper et al. 1998, PePiper \& Piper 2001). Based on these aspects, the emplacement of the Maronia pluton is related to 
post-collisional extension resulting from the underthrusting of the African plate under the European margin.

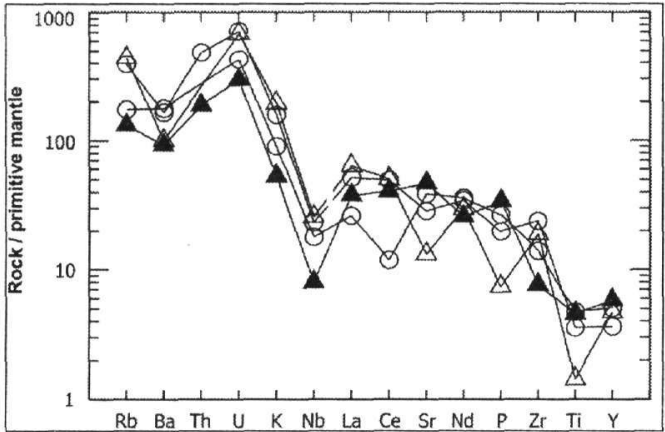

Figure 14. Primitive mantle-normalised trace element diagram of selected samples of the Maronia pluton, normalisation factors after Sun \& McDonough (1989). Symbols as in figure 2 .

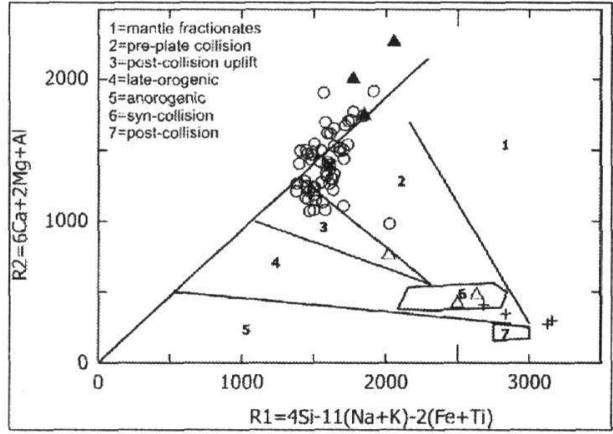

Figure 15. Plot of Maronia samples on the diagram R1-R2 (Batchelor \& Bowden 1985). Symbols as in figure 2 .

\section{ORIGIN}

Basic-intermediate group.

High incompatible element concentrations, enrichment of LREE (Fig. 3) and LILE (Fig. 14), low $\mathrm{Nd}$ initial isotopic values and high $\mathrm{Sr}$ initial isotopic values suggest either an enriched lithospheric mantle source (De Limá \& Nardi 1998, Chen et al. 2002) or derivation from alkaline mafic crustal rocks under large degrees of partial melting (Altherr et al. 2000). Such melts are generally characterized by low Mg\# $(<44.0)$ and high $\mathrm{Na}_{2} \mathrm{O}$ contents which are features not shown by the Maronia rocks.

Studies that have been conducted in the Aegean region have shown that shoshonitic and calcalkaline rocks that are emplaced in extensional environments can originate from the partial melting of an enriched hydrous mantle peridotite in the stability field of phlogopite, amphibole and garnet (Christofides et al. 1998, Pe-Piper \& Piper 2001). The existence of such a lithospheric mantle enriched in LREE and LILE has been accepted in the North Aegean region by studies of $\mathrm{Nd}$ and $\mathrm{Pb}$ isotopes (Pe-Piper et al 1998) and is considered as the source of the basic-intermediate group of the Maronia pluton.

Acid group.

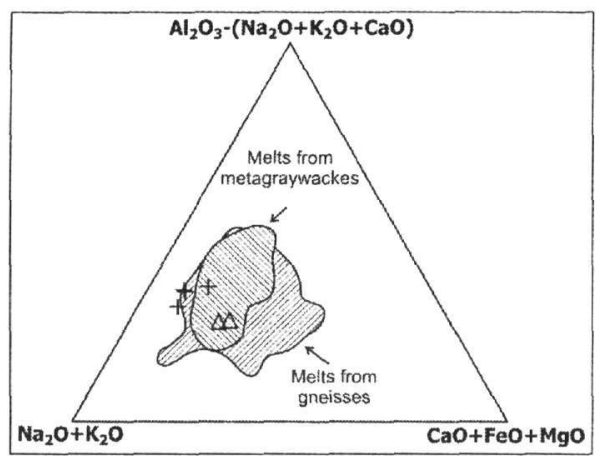

(a)

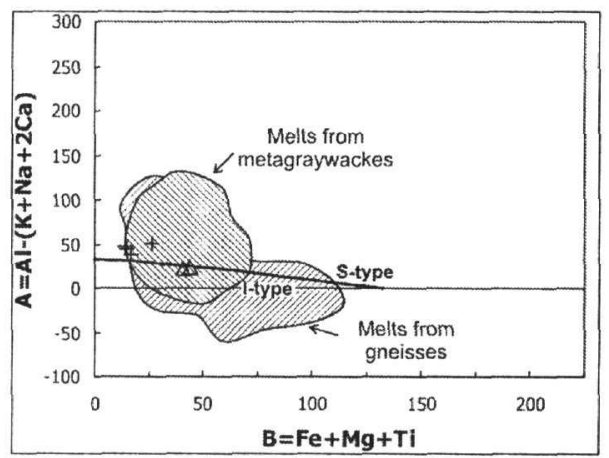

(b)

Figure 16. (a) Plot of the acid group on AFM diagram. (b) Plot of the acid group on the diagram A=Al$(\mathrm{K}+\mathrm{Na}+2 \mathrm{Ca})$ vs $\mathrm{B}=\mathrm{Fe}+\mathrm{Mg}+\mathrm{Ti}$. Symbols as in figure 2 . 
The geological relationships, the high $\mathrm{SiO}_{2}$ content, the compositional gaps observed in certain Harker diagrams and the lower $\mathrm{Sr}$ initial isotopic ratios exclude a genetic relationship between this and the basic-intermediate group.

The high $\delta^{18} \mathrm{O}$ isotopes suggest a crustal origin for these rocks (Altherr et al. 1998, Altherr \& Siebel 2002).

Peraluminous melts with $\mathrm{SiO}_{2}$ concentrations 68-72 wt.\%, similar in composition to the rocks of the acid group can derive from metagraywackes or gneisses, as shown in figure 16 . Since metagraywackes are absent from the broader area, gneisses are believed to be potential source rocks of the acid group.

A divergence between the $\mathrm{Gr}$ and the PmGr of the acid group, supported by REE patterns (Fig. 3), may be attributed to the formation of the latter at greater depths resulting in the increase of residual garnet reflected by the decrease of HREE.

\section{CONCLUSIONS}

Three main rock groups have been distinguished for the Maronia pluton: a) the basic, b) the intermediate and $\mathrm{c}$ ) the acid group. The rocks of the basic group show a high-K, calc-alkaline affinity while those of the in:ermediate group are characterized as shoshonites. The rocks of the acid group are considered as ultra-potassic.

Field relations, geochemical, and isotopic characteristics of the Maronia pluton indicate a rather composite evolution history. The rocks of the basic group, although more mafic than the other rocks comprising the pluton, show higher $\mathrm{Sr}$ isotopic values than the members of the intermediate group. Based on this observation, the basic group probably represents a magma that isotopically equilibrated with the members of the intermediate group at a certain point of their evolution. The evolution of the intermediate group can be described by an assimilation-fractional crystallization process (AFC) supported by theoretical isotopic and trace element modelling. The members of the acid group, with the exception of sample MP-90, possibly represent crustal melts (oxygen isotopic values $>10 \%$ ) that intruded the pluton. The granite sample MP-90 can result from fractional crystallization of an intermediate rock member or it can represent a separate magma cogenetic with the intermediate group. The mafic microgranular enclave displays the more primitive isotopic characteristics compared to the other Maronia rocks. It possibly represents a magma that intruded the Maronia pluton and crystallized near the emplacement level of the pluton. Rapid cooling prohibited isotopic equilibration between the enclaves and the pluton.

Geochemical characteristics of the Maronia pluton point to a subduction environment and reflect the composition of the magma source. The emplacement of the pluton is related to postcollisional extension resulting from the underthrusting of the African plate under the European margin.

A LILE- and LREE-enriched subcontinental lithospheric mantle is considered as the magma source of the basic and intermediate group.

The acid group probably has derived by the partial melting of crustal rocks and in particular, gneiss. A differentiation among the granite and porphyritic microgranite, supported by geochemical and isotopic signatures, is possibly due to the formation of the latter at greater depths.

\section{REFERENCES}

Altherr R., Henjes-Kunst F. Matthews A., Friedrichsen H. \& Hansen B.T. 1988. O-Sr isotopic variations in Miocene granitoids from the Aegean: evidence for an origin by combined assimilation and fractional crystallization. Contrib. Mineral. Petrol., 100, 528-541.

Altherr R., Holl A., Hegner E., Langer C. \& Kreuzer H. 2000. High-potassium, calc-alkaline I-type plutonism in the European Variscides: northern Vosges (France) and northern Schwarzwald (Germany). Lithos, 50, 5173.

Altherr R. \& Siebel W. 2002. I-type plutonism in a continental back-arc setting: Miocene granitoids and monzonites from the central Aegean Sea, Greece. Contrib. Mineral. Petrol., 143, 397-415.

Batchelor R.A. \& Bowden : ${ }^{3}$. (1985). Petrogenetic interpretation of granitoid rock series using multicationic parameters. Chem. Geol., 48, 43-55. 
Boynton V.W. (1984). Geochemistry of the rare earth elements: Meteorite studies. In: Henderson P. (ed.), Rare earth element geochemistry. Elsevier, 63-114.

Chen B., Jahn, B. \& Wei C. (2002). Petrogenesis of Mesozoic granitoids in the Dabie UHP complex, Central China: trace element and Nd-Sr isotope evidence. Lithos, 60, 67-88.

Christofides, G., Koroneos, A., Pe-Piper, G., Katirtzoglou, K. \& Chatzikirkou, A. (1999). Pre-Tertiary A-Type magmatism in the Serbomacedonian massif (N. Greece): Kerkini granitic complex. Bull. Geol. Soc. Greece, $33,131-148$.

Christofides, G., Soldatos, T., Eleftheriadis, G. \& Koroneos, A. (1998). Chemical and isotopic evidence for source contamination and crustal assimilation in the Hellenic Rhodope plutonic rocks. Acta Vulcanologica, 10(2), 305-318.

Davidson, J.P., Ferguson, K.M., Colucci, M.T. \& Dungan, M.A. (1988). The origin and evolution of magmas from the San Pedro-Pellado volcanic complex, S. Chile: multicomponent sources and open system evolution. Contrib. Mineral. Petrol., 100, 429-445.

De Lima, E.F. \& Nardi, L.V.S. (1998). The Lavras do Sul Shoshonitic Association: implications for the origin and evolution of Neoproterozoic shoshonitic magmatism in southernmost Brazil. J. South Amer. Earth Sci., 11(1), 67-77.

Del Moro, A., Innocenti, F., Kyriakopoulos, C., Manetti, P. \& Papadopoulos, P. (1988). Tertiary granitoids from Thrace (Northern Greece): Sr isotopic and petrochemical data. N. Jb. Miner. Abh., 159, 2, 113-135.

DePaolo, D.J. (1981). Trace element and isotope effects of combined wallrock assimilation and fractional crystallization. Earth Planet Sci. Letters, 53, 189-202.

Doryphoros K. (1990). The Maronia pluton and its metamorphic effects on the surrounding rocks of the Makri series. Ph.D. Thesis, National Technical University of Athens, 166pp. (in Greek with English abstract).

loannidis N., Chatzidimitriadis E., Mountrakis D. \& Kilias A. 1998. Study of metasedimentary formations of Upper Palaeozoic to Mesozoic age, from Nea Makri (Alexandroupolis area), W. Thrace/Greece. Bull. Geol. Soc. Greece, XXXI1/3, 79-89 (in Greek with English abstract).

Kouris C. 1980. Geological map of Greece, Mesi-Xilagani sheet, scale 1:50.000. I.G.M.E., Athens.

Mason P.R.D., Downes H., Thirlwall M.F., Seghedi I., Szakács A., Lowry D. \& Mattey D. 1996. Crustal assimilation as a major petrogenetic process in the east Carpathian Neogene and Quaternary continental margin arc, Romania. Journal of Petrology, 37(4), 927-959.

Mohamed F.H., Moghazi A.M. \& Hassanen M.A. 2000. Geochemistry, petrogenesis and tectonic setting of late Neoproterozoic Dokhan-type volcanic rocks in the Fatira area, eastern Egypt. Int. Journ. Earth Sciences, 88, 764-777.

Papadopoulos P. 1982. Geological map of Greece, Maronia sheet, scale 1:50.000. I.G.M.E., Athens.

Papadopoulou L. 2003. Mineral phase equilibria, crystallization conditions and evolution of the Maronia pluton, Thrace, Greece. Ph.D. thesis, University of Thessaloniki, 342pp (in Greek with English abstract).

Papadopoulou L., Christofides G., Bröcker M., Koroneos A., Soldatos T. \& Eleftheriadis G. 2001. Petrology, geochemistry and isotopic characteristics of the shoshonitic plutonic rocks from Maronia area, West Thrace, Greece. Bull. Geol. Soc. Greece, XXXIV/3, 967-976.

Peccerillo A. \& Taylor T.S. 1976. Geochemistry of Eocene calc-alkaline volcanic rocks from Kastamonu area, Northern Turkey. Contrib. Mineral. Petrol., 58, 63-81.

Pe-Piper G. 1998. The nature of Triassic extension-related magmatism in Greece: evidence from $\mathrm{Nd}$ and $\mathrm{Pb}$ isotope geochemistry. Geol. Mag., 135, 331-348.

Pe-Piper G. \& Piper D.J.W. 2001. Late Cenozoic, post-collisional Aegean igneous rocks: $\mathrm{Nd}, \mathrm{Pb}$ and $\mathrm{Sr}$ isotopic constraints on petrogenetic and tectonic models. Geol. Mag., 138(6), 653-668.

Rickwood P.C. 1989. Boundary lines within petrologic diagrams which use oxides of major and minor elements. Lithos, 22, 247-263.

Ricou L.E., Burg J.P., Godfriaux I. \& Ivanov Z. 1998. Rhodope and Vardar: the metamorphic and the olistostromic paired belts related to the Cretaceous subduction under Europe, Geodinamica Acta, 11, 6, 285309.

Streckeisen A. \& Le Maitre R.W. 1979. A chemical approximation to the modal QAPF classification of the igneous rocks. N. Jb. Min. Abh., 136, 169-206.

Sun S. \& McDonough W.F. (1989). Chemical and isotopic systematics of oceanic basalts: implications for mantle composition and processes. In: Saunders A.D., Norry M.J. (ed.), Magmatism in the ocean basins, Geol. Soc. (Spec. Publ.), London, 42, 313-345.

Visonà D. \& Zanferrari A. 2000. Some constraints on geochemical features in the Triassic mantle of the easternmost Austroalpine-Southalpine domain: evidence from the Karawanken pluton (Carinthia, Austria). Int. J. Earth Sci., 89, 40-51. 